University of Nebraska - Lincoln

DigitalCommons@University of Nebraska - Lincoln

2004

Streaks, multiplets, and holes: High-resolution spatio-temporal behavior of Parkfield seismicity

\author{
F. Waldhauser \\ Columbia University \\ W. L. Ellsworth \\ U.S. Geological Survey \\ D. P. Schaff \\ Columbia University \\ A. Cole \\ U.S. Geological Survey
}

Follow this and additional works at: https://digitalcommons.unl.edu/usgsstaffpub

Part of the Earth Sciences Commons

Waldhauser, F.; Ellsworth, W. L.; Schaff, D. P.; and Cole, A., "Streaks, multiplets, and holes: High-resolution spatio-temporal behavior of Parkfield seismicity" (2004). USGS Staff -- Published Research. 379.

https://digitalcommons.unl.edu/usgsstaffpub/379

This Article is brought to you for free and open access by the US Geological Survey at DigitalCommons@University of Nebraska - Lincoln. It has been accepted for inclusion in USGS Staff -- Published Research by an authorized administrator of DigitalCommons@University of Nebraska - Lincoln. 


\title{
Streaks, multiplets, and holes: High-resolution spatio-temporal behavior of Parkfield seismicity
}

\author{
F. Waldhauser, ${ }^{1}$ W. L. Ellsworth, ${ }^{2}$ D. P. Schaff, ${ }^{1}$ and A. Cole ${ }^{2}$ \\ Received 1 June 2004; revised 19 August 2004; accepted 2 September 2004; published 29 September 2004.
}

[1] Double-difference locations of $\sim 8000$ earthquakes from 1969-2002 on the Parkfield section of the San Andreas Fault reveal detailed fault structures and seismicity that is, although complex, highly organized in both space and time. Distinctive features of the seismicity include: 1) multiple recurrence of earthquakes of the same size at precisely the same location on the fault (multiplets), implying frictional or geometric controls on their location and size; 2) sub-horizontal alignments of hypocenters along the fault plane (streaks), suggestive of rheological transitions within the fault zone and/or stress concentrations between locked and creeping areas; 3 ) regions devoid of microearthquakes with typical dimensions of $1-5 \mathrm{~km}$ (holes), one of which contains the M6 1966 Parkfield earthquake hypocenter. These features represent long lived structures that persist through many cycles of individual events. INDEX TERMS: 7205 Seismology: Continental crust (1242); 7209 Seismology: Earthquake dynamics and mechanics; 7215 Seismology: Earthquake parameters; 7230 Seismology: Seismicity and seismotectonics. Citation: Waldhauser, F., W. L. Ellsworth, D. P. Schaff, and A. Cole (2004), Streaks, multiplets, and holes: High-resolution spatio-temporal behavior of Parkfield seismicity, Geophys. Res. Lett., 31, L18608, doi:10.1029/ 2004GL020649.

\section{Introduction}

[2] The Parkfield section of the San Andreas Fault (SAF) spans the transition between the creeping segment of the fault to the northwest and the locked segment to the southeast that last broke in the great 1857 Fort Tejon earthquake [Sieh, 1978]. Six characteristic earthquakes of $M \sim 6$ occurred between 1857 and 1966. The last two, in 1934 and 1966, initiated beneath Middle Mountain at the northwestern end of the locked section [Bakun and McEvilly, 1984; Bakun and Lindh, 1985]. Several thousand Parkfield earthquakes have been recorded since 1969 by the Northern California Seismic Network (NCSN), including 14 earthquakes with $M \geq 4$. Most of the earthquakes occurred directly on the SAF in the depth interval from $\sim 3$ to $12 \mathrm{~km}$.

[3] Waveform data recorded by the U.C. Berkeley High Resolution Seismic Network borehole revealed repeating earthquakes beneath Middle Mountain that recur numerous times at precisely the same location and with the same magnitude [Nadeau et al., 1995; Nadeau and McEvilly, 1997]. Earthquakes recorded by the NCSN surface network

\footnotetext{
${ }^{1}$ Lamont-Doherty Earth Observatory, Columbia University, Palisades, New York, USA.

${ }^{2}$ U.S. Geological Survey, Menlo Park, California, USA.
}

Copyright 2004 by the American Geophysical Union. 0094-8276/04/2004GL020649\$05.00 and located using a JHD technique or by joint inversion for location and velocity structure [Michelini and McEvilly, 1991; Eberhart-Phillips and Michael, 1993] did not provide the resolution required to investigate whether similar seismicity features occur elsewhere along the fault. Here we present double-difference locations of earthquakes recorded by the NCSN between 1969 and 2002 along a $60 \mathrm{~km}$ long zone centered on Middle Mountain (Figure 1). The highresolution event locations image detailed fault structures at seismogenic depths, and indicate that the seismicity is strongly organized in both time and space.

\section{Earthquake Relocation and Results}

[4] We relocated $\sim 8000$ earthquakes from 1969-2002 by applying the double-difference (DD) algorithm hypoDD [Waldhauser and Ellsworth, 2000; Waldhauser, 2001] to a combination of 2.5 million P-wave travel time differences derived from NCSN phase pick data and nearly 2 million accurate $(\sim 1 \mathrm{msec}$ in the optimal case) $\mathrm{P}$ - and S-wave differential times measured by waveform cross correlation [Schaff et al., 2004]. The DD algorithm inverts the weighted differential travel time residuals for event separation to remove uncertainties in the earth model outside the source region. Station distribution and P-velocity model used for relocation are shown in Figures $1 \mathrm{a}$ and $1 \mathrm{~b}$. The $\mathrm{S}$-velocity model is obtained by scaling the $\mathrm{P}$-velocities by a factor $1 / \sqrt{3}$.

[5] We first focus on events between 1984 and 2002, the time span for which digital waveforms are available from the NCSN in addition to phase picks. From a total of 5269 events we relocated 4505 events that had seven or more stations with an azimuthal gap less than $180^{\circ}$. Each event is linked to their nearest neighbors through commonly observed phases, with the average distance between linked events being $3 \mathrm{~km}$. A bootstrap analysis [see Waldhauser and Ellsworth, 2000] indicates relative location errors that range from a few meters (between nearby events constrained predominantly by cross-correlation data) to a few hundreds of meters (between events a few $\mathrm{km}$ apart and constrained by phase picks). The rms residuals decrease from $90 \mathrm{msec}$ to $3 \mathrm{msec}$ and $20 \mathrm{msec}$ for cross correlation and phase pick data, respectively. Note that the largest events are constrained by phase picks only and indicate the nucleation points (or hypocenters), while smaller events are predominantly constrained by cross correlation data that determine the relative positions of the center of moment release (or hypocentroids).

[6] The relocations present a sharp view of the seismicity, compared to the diffuse locations seen in the NCSN catalog, and concentrate along the mapped surface trace of the fault with little activity away from the fault (Figures 1c and 1d). 

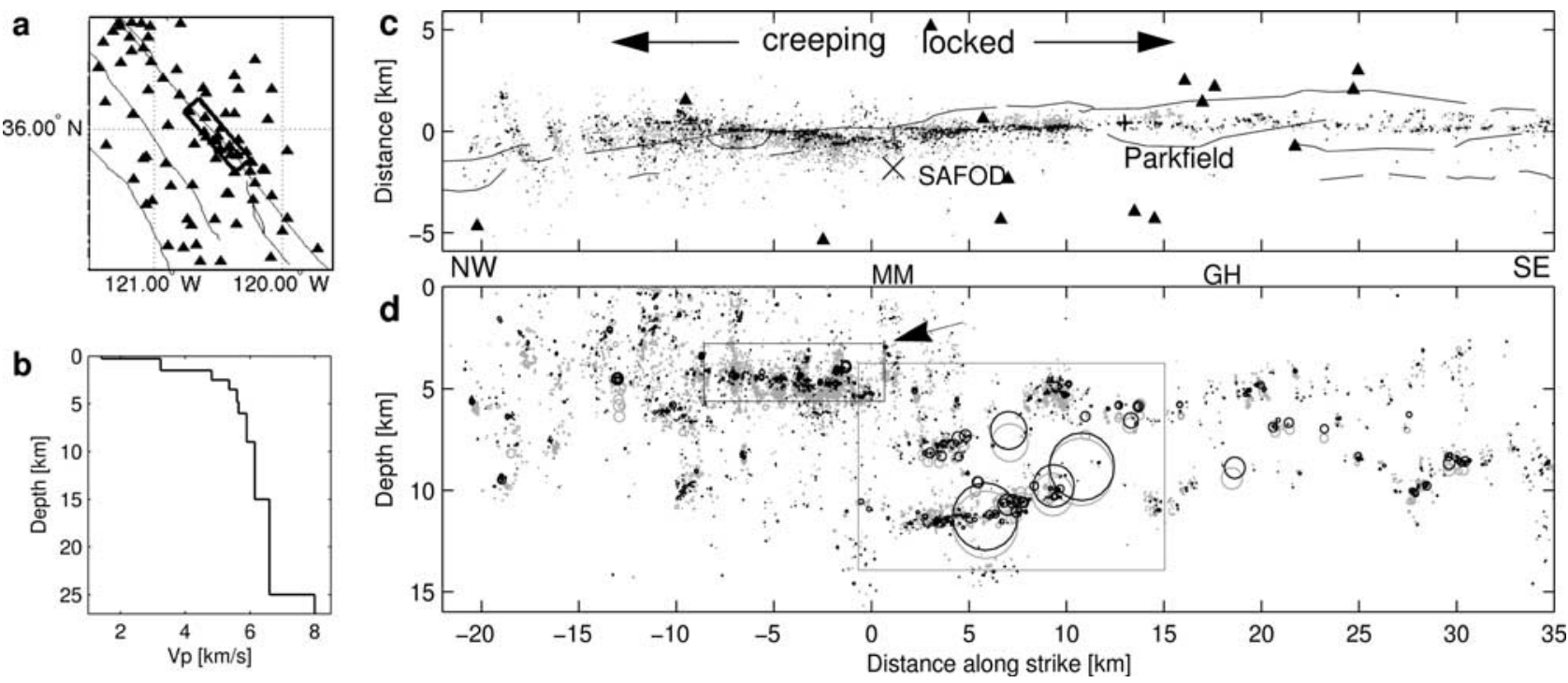

Figure 1. (a) Map of stations (triangles) and (b) velocity model used for relocations. (c) Map view (rotated into east west direction) and (d) longitudinal cross section of the relocated seismicity between 1984 and 2002 (black circles), and before relocation (gray circles). Lines in Figure 1c indicate the mapped surface traces of the SAF fault, ' + ' the town of Parkfield, and boxes in Figure 1d outline areas shown in Figures 2 and 3. Events in Figure 1d are represented by circles the size of a $3 \mathrm{MPa}$ constant stress drop source. $\mathrm{MM}=$ Middle Mountain; $\mathrm{GH}=$ Gold Hill. The drill site (' $\mathrm{x}$ ' in Figure 1c) of the San Andreas Fault Observatory at Depth (SAFOD) and the SAFOD target events (arrow in Figure 1d) are also shown.

The width of the seismically active fault imaged by the DD locations is substantially smaller compared to the width imaged by the network locations and the locations obtained in previous studies [Michelini and McEvilly, 1991; EberhartPhillips and Michael, 1993]. Widths of only a few tens of meters are imaged, and often they are not resolvably different from zero. Strong spatial clustering is observed, with the area of fault surface that slips seismically being much smaller than suggested by the catalog locations.

\section{Streaks, Multiplets, and Holes}

[7] The relocated seismicity forms characteristic structures of horizontal alignments of hypocenters (streaks), sources of repeating earthquakes (multiplets), and large areas devoid of earthquakes (holes). These structures are similar to those observed on the SAF about $100 \mathrm{~km}$ north of Parkfield [Rubin et al., 1999], on the Hayward fault [Waldhauser and Ellsworth, 2002], and on the Calaveras fault [Schaff et al., 2002].

[8] Seismicity at the southern terminus of the creeping central segment of the SAF principally occurs along the 'Big Streak', a $10 \mathrm{~km}$ long horizontal alignment of hypocenters at about $5 \mathrm{~km}$ depth (northwest of MM, Figures 1d and 2). Events along this streak are highly clustered, forming more than a hundred multiplets that include over a 1000 events ( $25 \%$ of the total seismicity). Different multiplets are not always coplanar, but occur on individual active patches that are nearly vertical and on the order of a few hundred meters offset from each other (Figure 2a). Such offsets are particularly apparent at the southeast end of the Big Streak, indicating that slip there is not accommodated along a single fault plane, but rather along individual subparallel active strands. Thurber et al. [2004] also report complex structure in this area. Towards the northwest end of the streak, offsets between active strands are smaller and a
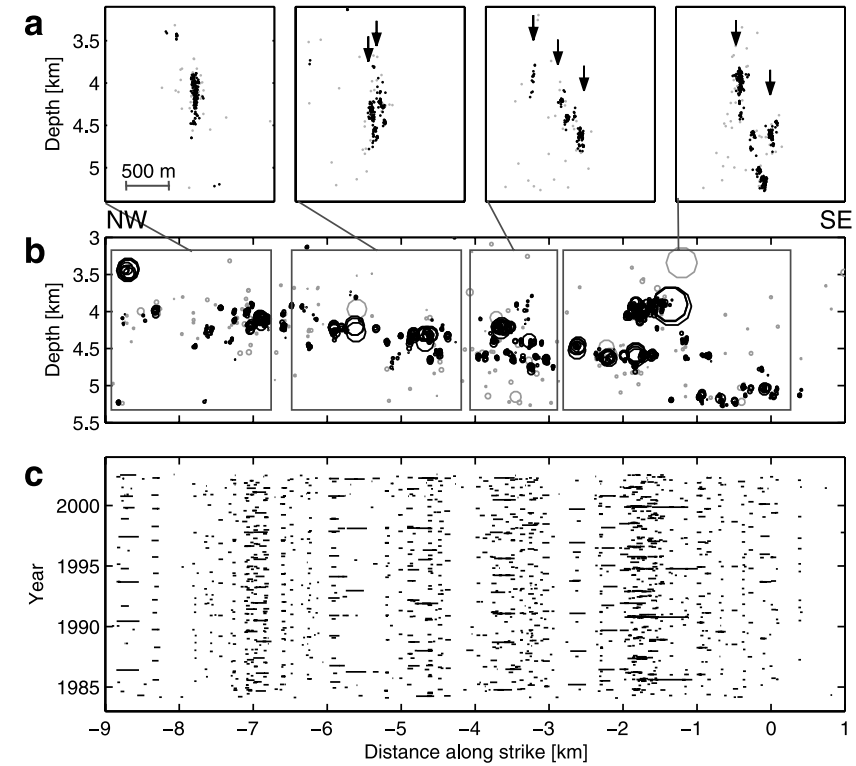

Figure 2. (a) Fault perpendicular (SW-NE) and (b) longitudinal (NW-SE) cross sections along the Big Streak' (see small box in Figure 1d). Boxes in Figure 2b include events shown in Figure 2a. Black and gray dots (Figure 2a) and circles (scaled by a $3 \mathrm{MPa}$ constant stress drop source, Figure $2 b$ ) indicate events mostly constrained by cross-correlation data and by phase picks, respectively. Arrows in Figure 2a point to separate active fault strands, reliably imaged by cross-correlation data within and across multiplets. (c) Year of occurrence as a function of location along the streak and rupture dimension. Note the spatial and temporal organization of the seismicity. The occasional spatial separation between repeating events of similar magnitudes is likely due to missing waveforms and the resulting less precise relative locations. 
single, corrugated or curved fault plane may also be possible.

[9] Events within each multiplet have nearly identical seismograms, are of similar magnitude, and rupture the same fault patch more than one time, thus showing the characteristics of repeating earthquakes [Vidale et al., 1994; Ellsworth, 1995; Nadeau et al., 1995]. The recurrence patterns of these earthquakes range from almost periodic to somewhat aperiodic, with the most regular events in relative spatial isolation from other earthquakes (Figure 2c), implying frictional or geometric controls on their location and size. Larger magnitudes generally have longer intervals (e.g., at $-1.4 \mathrm{~km}$ distance a $M \sim 3$ repeats 4 times in 18 years, Figure 2c), while smaller magnitudes have shorter intervals (e.g., at $-8.4 \mathrm{~km}$ distance a $M \sim 1$ repeats 14 times over the same interval). The robustness and the complexity of the faulting pattern suggest that the Big Streak marks the intersection of different rock strata with the fault plane.

[10] On the locked section of the fault the seismicity is generally deeper, mostly between 5 and $12 \mathrm{~km}$, with a few small events that locate as deep as $14 \mathrm{~km}$ (southeast of MM, Figure 1d). The seismicity is dominated by two slightly northwest plunging linear features between Middle Mountain and Gold Hill at about $11 \mathrm{~km}$ and $7 \mathrm{~km}$ depths (Figure 3). A closer examination of the deeper structure indicates that its dip is formed by short piecewise horizontal streaks (see also Figure 1d). Unlike the highly organized behavior within the Big Streak to the northwest, repeating earthquakes are rare, at least during the 18 years of observation. Many events along the deep streak occupy distinct, isolated areas on the fault plane, others locate in

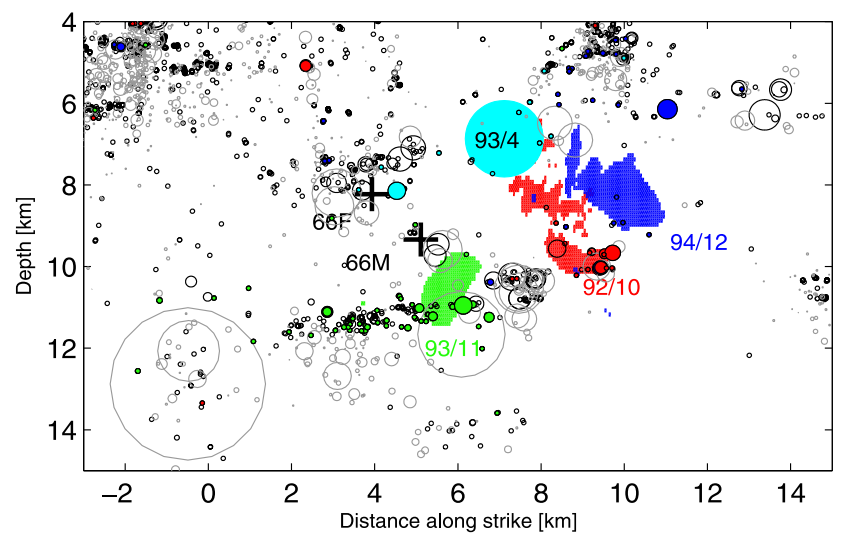

Figure 3. Detailed view of the seismicity in the area of the 1966 M6 hypocenter (see large box in Figure 1d). Gray circles denote events between 1969 and 1983, relocated with phase picks only, black circles events between 1984 and 2002, for which digital waveform data was used to relocate the events. Plus signs indicate approximate location of the 1966 mainshock (66M) and its 17 minutes foreshock (66F). Slip models of Fletcher and Spudich [1998] are shown for three $M 4.3-5$ earthquakes that occurred in Oct. 20, 1992 (red), Nov. 14, 1993 (green), and Dec. 20, 1994 (blue). The April 1993 event (cian) is represented by a $3 \mathrm{MPa}$ circular rupture model. 5 days aftershocks for each of the four larger events are indicated by the corresponding color of their main shock. Events with $M<2$ are represented as $M=2$.

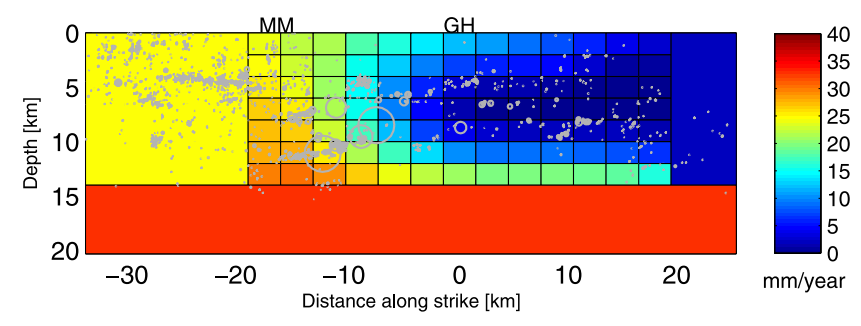

Figure 4. Relocated seismicity 1984-2002 superimposed on slip rate (mm/year) inferred from trilateration and GPS data between 1991-1998 [Murray et al., 2001]. MM = Middle Mountain; GH = Gold Hill.

close proximity to other events, and few events share the same fault patch. This pattern is similar to that observed along a streak on the northern Hayward fault at a depth of $10 \mathrm{~km}$ [Waldhauser et al., 1999], where it may mark stress concentrations at the transition from locked (above) to creeping (below) behavior.

[11] The two streaks of seismicity bound a large aseismic area that contains the 1966 M6 mainshock hypocenter (66M, Figure 3), which is known to have also been the initiation point of the 1934 earthquake [Bakun and McEvilly, 1979]. Three moderate size earthquakes with magnitudes of $M=4.6$ (Oct. 20, 1992), $M=5.0$ (Nov. 14, 1993), and $M=5.0$ (Dec. 20, 1994) nucleated within the deeper streak (or in the case of the 94/12 event at its southeastern extension) and propagated into the hole containing the 1966 hypocenter [Fletcher and Spudich, 1998] (Figure 3). For all three events it appears that the initial phase of rupture at or near the hypocenter has the largest stress change [Fletcher and Guatteri, 1999], with stress drops of $3.8 \mathrm{MPa}$ for the $92 / 10$ event (which also has the smallest magnitude), and about $45 \mathrm{MPa}$ and $60 \mathrm{MPa}$ for the 93/11 and 94/12 events, respectively. The 93/11 event, which nucleated from within the deepest part of the streak, is the most impulsive one. The stress release pattern for the other two events is more complex with a greater spatial extent. Fletcher and Guatteri [1999] argue that the high seismicity of this zone releases most of the stress and that the average stress level over the rupture zone remains low, so that rupture propagation is not easily sustained over a large area. Although the three $M \geq 4.6$ events did not grow into a typical Parkfield mainshock, they triggered two A-level and one B-level alerts and were the largest events to occur at Parkfield since the 1966 mainshock. Note that the foreshocks (66F, Figure 3) to both the 1934 and 1966 mainshocks locate within or immediately below the upper seismic streak.

[12] Aftershocks within 5 days of each of the three $M \geq$ 4.6 events concentrate predominantly along the deeper seismic structure (Figure 3). In particular, aftershocks of the 93/11 event occupy the entire length of the deepest part of the streak, contributing substantially to its delineation. Aftershocks to the $92 / 10$ event also concentrate in the substructure from which the mainshock nucleated. These aftershocks were caused by repeated movement within a narrow zone that was activated at the time of the mainshock. This relationship is also supported by aftershocks from a $M=4.5$ event that occurred in April 1993 in the upper streak (93/4 in Figure 3, represented by a circular $3 \mathrm{MPa}$ 
stress drop source). They locate in the same structure as the mainshock, with a few aftershocks close to the 1966 foreshock (66F). An exception is the 94/12 event, which does not nucleate from a preexisting cluster, and seems to generate most of its aftershocks in a preexisting cluster about $3 \mathrm{~km}$ away (at $5 \mathrm{~km}$ depth and $10 \mathrm{~km}$ model distance, Figure 3), and in the cluster that includes the 92/10 event.

\section{Discussion and Conclusion}

[13] An interesting finding from these new data is the persistence of the seismicity pattern over the past 18 years. This is especially striking along the Big Streak on the creeping fault which is robust through many cycles of individual events. To investigate whether the larger events on the locked section might be repeats of earlier ones, we have extended the observational period by including earthquakes between 1969 and 1983 (the time span from the beginning of the NCSN bulletin and before digital waveforms were available) in the DD relocation process, linking them to the post 1984 events with phase picks only (gray circles in Figure 3). These relocations show that events before 1984, although more diffuse, concentrate into the same structures defined by the post 1984 events, indicating that they persist for over 30 years, or through about $1 / 2 \mathrm{~m}$ of fault slip. The 93/11 $M=5$ event may be indeed the repeat of a somewhat smaller $(M=4.6)$ event that occurred in 1975. These results suggest that larger earthquakes do not seem to change the distribution of microseismicity significantly. Such a behavior was also found on the Calaveras fault, where the general seismicity structure survived the 1984 Morgan Hill earthquake [Schaff et al., 2002].

[14] Interseismic slip rates between 1991 and 1998 estimated from trilateration and GPS data indicate that the seismicity hole containing the 1966 hypocenter is an area of transition between the creeping segment to the northwest and the fully locked segment to the southeast [Murray et al., 2001] (Figure 4). The deep streak at about $12 \mathrm{~km}$ depth appears to mark the transition from the deeper creeping part to the shallower locked or partially locked area that contains the 1966 hypocenter. Near Gold Hill and to the southeast, the zone between about 5 and $10 \mathrm{~km}$ depth seems to be fully locked (dark blue in Figure 4). It is interesting to note that this band of frictionally locked fault surface is bounded above and below by a few earthquakes which appear to form the continuation of the lower and upper seismic streaks that exist near Middle Mountain. Similar to observations made along the East Rift of Kilauea [Gillard et al., 1996] and the northern Hayward fault [Waldhauser and Ellsworth, 2002], the streaks of seismicity on the locked section of the SAF might represent narrow zones of steep slip rate gradients. On the creeping section, however, they are suggestive of rheological transitions within the fault zone.

[15] Acknowledgments. We thank J. Fletcher for providing us with his slip models, J. Murray for her slip rate model, the NCEDC for access to their data, and St. Prejean, C. Thurber, A. Rubin and A. Lomax for useful comments. This study was supported by the Department of Geophysics of Stanford University and by the USGS/NEHRP grant 03HQGR0004. This is contribution number 6657 of the Lamont-Doherty Earth Observatory, Columbia University.

\section{References}

Bakun, W. H., and A. G. Lindh (1985), The Parkfield, California, earthquake prediction experiment, Science, 229, 619-624

Bakun, W. H., and T. V. McEvilly (1979), Earthquakes near Parkfield, California: Comparing the 1934 and 1966 sequences, Science, 205, $1375-1377$.

Bakun, W. H., and T. V. McEvilly (1984), Recurrence models and Parkfield, California, earthquakes, J. Geophys. Res., 89, 3051-3058.

Eberhart-Phillips, D. M., and A. J. Michael (1993), Three-dimensional velocity structure, seismicity and fault structure in the Parkfield region, central California, J. Geophys. Res., 98, 15,737-15,758.

Ellsworth, W. L. (1995), Characteristic earthquakes and long-term earthquake forecasts: Implications of central California seismicity, in Urban Disaster Mitigation: The Role of Science and Technology, edited by F. Y. Cheng and M. S. Sheu, pp. 1-14, Elsevier Sci., New York.

Fletcher, J. B., and M. Guatteri (1999), Stress drop for three M 4.3-4.7 (1992 - 1994) Parkfield, CA, earthquakes, Geophys. Res. Lett., 26, $2295-$ 2298.

Fletcher, J. B., and P. Spudich (1998), Rupture characteristics of the three M 4.7 (1992-1994) Parkfield earthquakes, J. Geophys. Res., 103, 835854.

Gillard, D., A. M. Rubin, and P. Okubo (1996), Highly concentrated seismicity caused by deformation of Kilauea's deep magma system, Nature, $384,343-346$.

Michelini, A., and T. V. McEvilly (1991), Seismological studies at Parkfield I: Simultaneous inversion for velocity structure and hypocenters using cubic B-splines parametrization, Bull. Seismol. Soc. Am., 81, 524-552.

Murray, J. R., P. Segall, P. Cervelli, W. Prescott, and J. Svarc (2001), Inversion of GPS data for spatially variable slip-rate on the San Andreas Fault near Parkfield, CA, Geophys. Res. Lett., 28, 359-362.

Nadeau, R. M., and T. V. McEvilly (1997), Seismological studies at Parkfield V: Characteristic microearthquake sequences as fault-zone drilling targets, Bull. Seismol. Soc. Am., 87, 1463-1472.

Nadeau, R. M., W. Foxall, and T. V. McEvilly (1995), Clustering and periodic recurrence of microearthquakes on the San Andreas fault at Parkfield, California, Science, 267, 503-507.

Rubin, A. M., D. Gillard, and J.-L. Got (1999), Streaks of microearthquakes along creeping faults, Nature, 400, 635-641.

Schaff, D. P., G. Bokelmann, G. C. Beroza, F. Waldhauser, and W. L. Ellsworth (2002), High-resolution image of Calaveras fault seismicity, J. Geophys. Res., 107(B9), 2186, doi:10.1029/2001JB000633.

Schaff, D. P., G. Bokelmann, W. L. Ellsworth, E. Zanzerkia, F. Waldhauser, and G. C. Beroza (2004), Optimizing correlation techniques for improved earthquake location, Bull. Seismol. Soc. Am., 94, 705-721.

Sieh, K. E. (1978), Slip along the San Andreas fault associated with the great 1857 earthquake, Bull. Seismol. Soc. Am., 68, 1421-1448.

Thurber, C., S. Roecker, H. Zhang, S. Baher, and W. Ellsworth (2004), Fine-scale structure of the San Andreas fault zone and location of the SAFOD target earthquakes, Geophys. Res. Lett., 31, L12S02, doi:10.1029/2003GL019398.

Vidale, J. E., W. L. Ellsworth, A. Cole, and C. Marone (1994), Variations in rupture process with recurrence interval in a repeated small earthquake, Nature, 368, 624-626.

Waldhauser, F. (2001), HypoDD: A computer program to compute doubledifference hypocenter locations, U.S. Geol. Surv. Open File Rep., 01-113, $25 \mathrm{pp}$.

Waldhauser, F., and W. L. Ellsworth (2000), A double-difference earthquake location algorithm: Method and application to the northern Hayward fault, California, Bull. Seismol. Soc. Am., 90, 1353-1368.

Waldhauser, F., and W. L. Ellsworth (2002), Fault structure and mechanics of the Hayward fault, California, from double-difference earthquake locations, J. Geophys. Res., 107(B3), 2054, doi:10.1029/2000JB000084.

Waldhauser, F., W. L. Ellsworth, and A. Cole (1999), Slip-parallel seismic lineations along the northern Hayward fault, California, Geophys. Res. Lett., 26, 3525-3528.

A. Cole and W. L. Ellsworth, U.S. Geol. Survey, 345 Middlefield Rd., MS 977, Menlo Park, CA 94025, USA.

D. P. Schaff and F. Waldhauser, Lamont-Doherty Earth Observatory, Columbia University, 61 Route 9W, Palisades, NY 10964, USA. (felixw@1deo.columbia.edu) 